\title{
PENGARUH MODEL PEMBELAJARAN VALUE CLARIFICATION TECHNIQUE TERHADAP SOCIAL SKILL MAHASISWA
}

\author{
Fatma Sukmawati ${ }^{1)}$, Muhammad Jafar Nashir ${ }^{2)}$ \\ 1'Fakultas Tarbiyah,Institut Islam Mamba'ul 'Ulum Surakarta \\ email: fatmasukma76@gmail.com \\ ${ }^{2}$ Fakultas Tarbiyah, Institut Islam Mamba'ul 'Ulum Surakarta \\ email: nasirwahid@gmail.com
}

\begin{abstract}
Ideally, learning in the Education unit emphasizes three aspects, namely cognitive, affective and motoric. However, in reality, the affective aspect is still rarely considered, such as social skills. The purpose of this research is to find out whether there is a significant difference between the VCT model and the expository model on students' social skills. The research subjects were 100 students of the Islamic Religious Education study program at the Mambaul Ulum Institute, Surakarta. This type of research is a Quasi Experimental Research. The research design used a posttest only control group design where there were 2 research classes, namely the experimental class by applying the VCT model while the control class applying the expository model. The results of the study obtained a significance of 0.000, which means that there is a significant difference between the VCT t model and the expository model on students' social skills.
\end{abstract}

Keyword: Value Clarification Technique model, Social Skill

Abstrak : Idealnya, pembelajaran di satuan Pendidikan menekankan pada tiga aspek, yaitu kognitif, afektif dan motoric. Namun, pada kenyataanya, aspek afektif masih jarang diperhatikan seperti social skill. Tujuan dari dilaksanakanya penelitian ini yaitu mengetahui apakah ada perbedaan yang signifikan antara model VCT dengan model ekspositori terhadap social skill mahasiswa. Subjek penelitian adalah mahasiswa program studi Pendidikan Agama Islam Institut Mambaul Ulum Surakarta yang berjumlah 100 orang. Jenis penelitian ini merupakan Quasi Experimental Research. Adapun desain penelitiannya menggunkan posttest only control group design dimana terdapat 2 kelas penelitian, yaitu kelas eksperimen dengan menerapkan model VCT sedangkan kelas control menerapkan model eskpositori. Hasil penelitian diperoleh signifikansi yaitu 0,000, yang artinya terdapat perbedaan yang signifikan antara model VCT tdengan model ekspositori terhadap social skill mahasiswa.

Kata kunci: Model Value Clarification Technique, Social Skill

\section{PENDAHULUAN}

Kegiatan pembelajaran di perguruan tinggi dilakukan oleh pendidik sesuai dengan tujuan pembelajaran. Terdapat tiga kagetori tujuan pembelajaran pada tingkat satuan pendidikan yaitu berkaitan dengan kognitif (kecerdasan dan intelektual), afektif berkaitan dengan sikap, moral, dan nilai) dan yang ketiga berkaitan dengan bidang psikomotor (Anderson, 1956). Pebelajar dikatakan berhasil jika terjadinya perubahan pada bidang kognitif, afektif, dan psikomotorik ke arah yang lebih baik lagi (Hyder \& Bhamani, 2016). Namun demikian, pada kenyataanya tujuan pembelajaran masih menitikberatkan pada kemampuan kognitif saja, sedangkan pada kemampuan afektif dan psikomotorik masih kurang mendapat perhatian.

Salah satu penerapan aspek afektif sangat penting dalam pendidikan 
diperguruan tinggi adalah social skill. Social Skill mahasiswa merupakan suatu kemampuan yang dibutuhkan untuk beradaptasi serta berinteraksi sesuai dengan harapan di lingkungannya. Dalam berhubungan dengan lingkungan sosial, keterampilan sosial dapat diwujudkan dengan interaksi, saling bertatap muka, tanggung jawab individu dan kelompok (Bremer, 2004). Social skill sangat berpengaruh dalam proses belajar siswa. Ketika peserta didik mempunyai keterampilan sosial lemah, akan menyebabkan mereka mengalami keterlambatan dalam belajar, peserta didik kurang perhatian dengan materi belajar, dan emosi yang kurang stabil yang berakibat kurangnya motivasi (Sharma et al., 2016).

$$
\text { Dong Hwa \& Juhu (2003) }
$$

menjelaskan bahwa seseorang yang mempunyai social skill yang baik jika individu tersebut memiliki sikap: empati terhadap orang lain, memiliki kesadaran sosial yang tinggi, dapat berinteraksi dengan baik. Siswa yang memiliki rasa empati tinggi dapat merasakan dirinya berada pada posisi orang lain. Ia seakan-akan dapat merasakan kejadian yang dialami oleh temanya. Sehingga menjadi pendengar yang baik dan tidak merendahkan orang lain merupakan hasil dari keterampilan sosial yang tinggi (Lawhon \& Lawhon, 2000). Indicator social skill merupakan keadaan seseorang untuk bisa peka terhadap keadaan di lingkungan sekitarnya. Tindakan tidak peduli terhadap masalah dalam kelompoknya merupakan ciri dari seseorang memiliki keterampilan sosial yang rendah. Indikator untuk terampil berinteraksi dengan baik merupakan perwujudan dari individu tersebut mudah berkolaborasi dengan orang lain.

Rendahnya social skill mahasiswa di Institut Islam Mamba'ul 'Ulum Surakarta ditunjukan seperti berikut ini. Pertama, pembelajaran tidak pernah dilibatkan secara aktif oleh mahasiswa. Kedua, pembelajaran masih menggunkan metode ceramah, sehingga minimnya kegiatan kelompok yang dilakukan selama proses pembelajaran. Hal ini berakibat kurangnya kolaborasi dan interaksi pada proses belajar. Ketiga, rendahnya tanggung jawab mahasiswa terhadap pekerjaan atau tugas yang diberikan. Keempat, kurangnya sikap pengendalian diri serta empati kepada sesama teman, hal ini ditunjukan dengan masih adanya mahasiswa yang suka bercanda sendiri di kelas ketika teman yang lain mengemukakan pendapatnya.

Berdasarkan dengan temuan yang diperoleh, perlunya perhatian dalam aspek social skill mahasiswa supaya terjadinya perbaikan dalam proses pembelajaran. Salah satu alternative untuk memperbaiki keadaan yang ada yaitu dengan mengaplikasikan model pembelajaran Value Clarification Technique (VCT), diharapkan permasalahan yang terjadi selama ini dapat diatasi. Model Pembelajaran VCT ini menjadikan siswa terbantu dalam menentukan value atau nilai yang mendalam (Awiria et al., 2019). Value merupakan standar dalam menentukan apakah itu baik atau buruk. Model VCT termasuk dalam kategori model yang induktif (Yudhistira et al., 2015). Hal ini dapat dianalogikan pendidik dapat menunjukan pebelajar untuk belajar secara berkelompok senajutnya, pebelajar membandingkan yang sudah diperoleh dengan pengalaman pebelajar yang lain Pendidik memiliki peran untuk membantu pebelajar dalam mendapatkan kesadaran tentang nilai yang sudah dimiliki mereka.

Pemilihan model VCT dikarenakan sesuai dengan permasalahan yang ditemukan dilapangan seperti mengenai aspek social skill mahasiswa yang masih rendah. Teknik dalam mengklarifikasikan nilai didalam aktivitas pembelajaran bisa menaikan kemampuan pebelajar ketika dihadapkan utuk : 1) memutuskan serta 
memilih, 2) komunikasi untuk mengungkapkan gagasan serta keyakinan, value dan juga perasaannya, 3) empati terhadap perasaan orang lain dan serta merasakan apa yang orang lain rasa, 4) mengungkapkan sikap setuju atau penolakan terhadap argumen orang lain, 5) mempunyai pendirian yang teguh dan kuat serta bertanggung jawab apa yang telah ditetapkannnya (Sariani dkk, 2016). Berdasarkan latar belakang diatas, penelitian ini memiliki tujuan yaitu mengetahui pengaruh model VCT terhadap social skill mahasiswa. Penelitian ini diharapkan dapat berkontribusi pada kualitas pembelajaran di perguruan tinggi.

\section{METODE PENELITIAN}

Jenis penelitian ini merupakan Quasi Experimental Research atau penelitian eksperimental semu. Variabel independen atau bebas pada penelitian ini yaitu model pembelajaran Value Clarification Technique (VCT) Variabel dependen atau variabel terikatnya yaitu social skill mahasiswa. Selanjutnya, untuk penelitian eksperimen ini, terdapat du akelas, yaitu kelas kelas kontrol dan kelas eksperimen. Kelas eksperimen menerapkan model VCT dalam proses kegiatan pembelajaran, dan kelas kontrol memakai model ekspositori (pembelajaran langsung). Adapun desain penelitiannya menggunkan posttest only control group design. Desain penelitian dapat ditunjukan pada Tabel 1 .

Tabel 1. Rancangan penelitian

\begin{tabular}{ccc}
\hline Kelas & Treatment & Posttest \\
\hline Eksperiment & $\mathrm{X} 1$ & $\mathrm{P} 1$ \\
\hline Kontrol & $\mathrm{X} 2$ & $\mathrm{P} 2$ \\
\hline
\end{tabular}

Keterangan:

X1: Model VCT

X2: Model Ekspositori

P1: Postest Kelas Eksperimen

P2: Postest Kelas Kontrol

Sampel pada penelitian berjumlah 100 mahasiswa program studi Pendidikan Agama Islam Institut Islam Mamba'ul 'Ulum Surakarta. Pembagian sampel dalam kelas eksperimen berjumlah 50 mahasiswa dan kelas control berjumlah 50 mahasiswa. Teknik pengambilan sample yaitu purposive sampling. Hal ini dikarenakan penentuan sampel yang didasarkan pada pertimbangan peneliti mengenai sampel mana yang sesuai dan dianggap dapat mewakili suatu populasi.

Instrumen penelitian yang digunakan pada kelas ekperimen dan kelas control yaitu berupa angket social skill. Angket yang digunakan berupa kuisioner dengan skala likert dengan rentang jawaban 1 sampai 4 berjumlah 25 item. Kuesioner keterampilan sosial dalam penelitian ini diadaptasi berdasarkan (Tapia-Gutierrez \& Delgado, 2015). Terdapat lima dimensi dalam instrumen keterampilan sosial yaitu solidaritas dan empati, berkomunikasi, bekerjasama, pengendalian diri, dan penyelesaian konflik. Sebelum memulai perlakukan diadakan uji keseimbangan untuk mengetahui kesamaan kelas baik pada kelas eksperimen maupun kelas kontrol. Selanjutnya, dilakukan pula uji prasyarat seperti uji validitas dan reabilitas sebelum melakukan uji hipotesis.

\section{HASIL DAN PEMBAHASAN}

Langkah sebelum dilakukan perlakuan di kelas eksperimen dilakukan uji 
keseimbangan untuk mengetahui apakah pada kedua kelas memiliki kemampuan yang sama atau tidak. Hasil dari uji keseimbangan dapat dipaparkan Tabel 2.

Tabel 2. Hasil Rangkuman Uji Keseimbangan

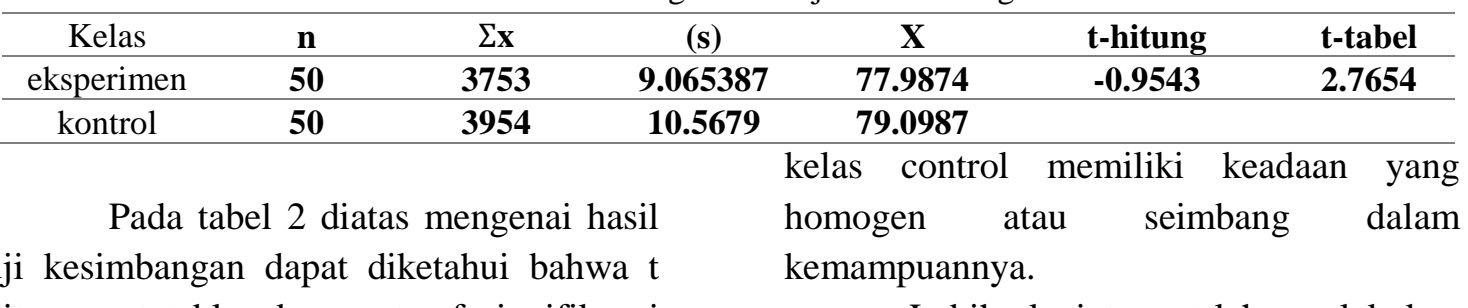
hitung $<\mathrm{t}$ table, dengan taraf signifikansi alfa sebesar $=0,05$. Sehingga dapat ditarik kesimpulan bahwa kelas eksperimen dan

Lebih lanjut, setelah perlakukan dikelas eksperimen dengan menggunakan model VCT diperoleh seperti pada Tabel 3.

Tabel 3. Rangkuman Data Analisis Pada Kelas VCT dan Kelas Ekspositori

\begin{tabular}{ccc}
\hline Data & Kelas Eksperimen (VCT) & Kelas Kontrol (Ekspositori) \\
\hline $\mathrm{N}$ & $\mathbf{5 0}$ & $\mathbf{5 0}$ \\
\hline Score Tertinggi & 25 & $\mathbf{2 0}$ \\
\hline Score Terendah & $\mathbf{2 0}$ & $\mathbf{1 5}$ \\
\hline Mean & $\mathbf{2 3 , 5}$ & $\mathbf{1 7 , 5}$ \\
\hline SD & $\mathbf{4 , 7 8}$ & $\mathbf{1 0 , 3 4}$ \\
\hline Varians & $\mathbf{6 7 , 5 4}$ & $\mathbf{1 1 0 , 6 5}$
\end{tabular}

Dari Table 3 dapat dilihat bahwa score pada kelas ekaperimen (VCT) dan kelas control (ekspositori) memiliki data yang berbeda. Score rata-rata pad akelas VCT berjumlah 23,4 sedangkan pada kelas control berjumlah 17,5. Begitu pula pada SD atau standar deviasi kelas eksperimen 4,78 sedangkan pada kelas control 10,34. Lebih lanjut menjelaskan varians pada kelas VCT dan kelas ekspositori masing-masing 67,54 dan 110, 65 .
Penelitian ini akan menngunkan uji hipotesis dengan perhitungan Uji-t satu jalur. Diadakan Uji hipotesis bertujuan untuk mengetahui apakah terdapat perbedaan yang signifikan social skill pada kelas eksperimen (VCT) dengan kelas control (Ekspositori). Berikut Rangkuman uji-t pada kedua kelas dapat dilihat pada Table 4.

Tabel 4. Rangkuman Uji-t

\begin{tabular}{llll}
\hline Kelas & Signifikasi & t-hitung & t-tabel \\
\hline Eksperimen (VCT) & 0,000 & 5,837 & 2,064 \\
\hline Kontrol (Ekspositori) & & & \\
\hline
\end{tabular}

Pada Tabel 4 dapat dilihat bahwa hasil signifikansi yaitu 0,000 , dengan thitung sebesar 5,837 dan t-tabel 2,064. Dari data tersebut dapat dinilai bahwa $0,000<$ 0,05 , dimana nilai signifikasi $\alpha=0,05$, dan juga ditunjukan bahwa thitung $>$ ttabel. Hal ini menjelaskan bahwa $\mathrm{H} 1$ diterima, maka H0 ditolak, dapat diartikan bahwa terdapat perbedaan yang signifikan social skill mahasiswa antara kelas VCT dengan kelas 
ekspositori. Hal ini dapat diartikan juga social skill mahasiswa prodi Pendidikan Agama Islam Institut Islam Mamba'ul 'Ulum (IIM) Surakarta dengan menggunakan model VCT lebih tinggi dibandingkan mahasiswa yang menerapkan model ekspositori atau pembelajaran langsung.

Perguruan tinggi sebagai lembaga formal penting dalam dunia pendidikan, tidak hanya mengembangkan kemampuan akademik kognitif mahasiswa saja, namun juga harus mengembangkan keterampilan sosial. Sejalan dengan pendapar beberapa peneliti, kemampuan yang harus dimiliki oleh peserta didik meliputi kemmapuan kognitif, social, dan pribadi (Nurasiah, 2019;
Haris \& Gunansyah, 2013). Lebih lanjut menjelaskan bahwa pendidikan bukan hanya menciptakan, memebentuk kepandaian atau kecerdasan pebelajar, namun pengembangan sikap, moral dan perilaku sesuai dengan norma yang berlaku juga tidak kalah pentingnya. Salah satu model pembelajaran yang digunakan untuk mendukung terbentuknya sikap dan keterampilan social yaitu Value Clarification Technique (VCT). Model VCT ini memiliki sintak atau langkah pembelajaran sesuai dengan Tabel 5.

Tabel 5. Sintak Model Pembelajaran Value Clarification Technique (VCT)

\begin{tabular}{lll}
\hline No & Kegiatan Pendidik & Kegiatan Peserta Didik \\
\hline $\mathbf{1}$ & $\begin{array}{l}\text { Pendidik menciptakan serta mencari media yang } \\
\text { mendukung materi pembelajaran seperti contoh } \\
\text { keadaan atau tindakan yang memuat value } \\
\text { kontras dengan topik materi }\end{array}$ & $\begin{array}{l}\text { Membuktikan dan menetukan argument } \\
\text { yang tepat, pada tahap ini sudah } \\
\text { ditanamkan value/nilai dan konsep sesuai } \\
\text { dengan tema materi. }\end{array}$ \\
\hline $\mathbf{2}$ & $\begin{array}{l}\text { Pengajar melemparkan stimulus dengan } \\
\text { membacakan histori, cerita, menampilkan video, } \\
\text { gambar }\end{array}$ & $\begin{array}{l}\text { Malalui pertanyaan yang diberikan, Peserta } \\
\text { didik beragumen dan menentukan } \\
\text { klarifikasi pendirian }\end{array}$ \\
\hline $\mathbf{3}$ & $\begin{array}{l}\text { Pendidik memberi waktu kepada peserta didik } \\
\text { untuk berdiskusi/beridalog dengan temannya } \\
\text { berkaitan dengan stimulus yang diberikan tadi }\end{array}$ & $\begin{array}{l}\text { Pebelajar melakukan dialog terpimpin } \\
\text { berakaitan pertanyaan pendidik secara } \\
\text { individual atau kelompok di kelas. }\end{array}$ \\
\hline $\mathbf{4}$ & $\begin{array}{l}\text { Pengajar mampu mengundang, memfasilitasi, } \\
\text { dan melibatkan potensi yang ada dalam }\end{array}$ & $\begin{array}{l}\text { Peserta didik menjalankan konsep } \\
\text { pengetahuannya sesuai dengan potensi } \\
\text { lingkungan kehidupan peserta didik. }\end{array}$ \\
& & $\begin{array}{l}\text { yang ada dalam lingkungan kehidupan } \\
\text { pebelajar. }\end{array}$ \\
\hline
\end{tabular}

Sumber: Awiria dkk (2019)

Dalam penerapan VCT, terdapat langkah atau sintak seperti padal tahap pengembangan dialog peserta didik yang diselenggarakan secara terbuka dan santai. Hal ini bertujuan supaya pebelajar bebas menyatakan pendapatnya berkaitan value yang ada di masyarakat. Pada hasil penelitian diatas, social skill mahasiswa prodi Pendidikan Agama Islam IIM Surakarta mengalami perubahan setelah menerapkan model pembelajaran Value Clarification Technique (VCT). Beberapa indicator social skill yang diteliti dalam penelitian ini merujuk pada pendapat TapiaGutierrez \& Delgado (2015). Terdapat lima dimensi dalam instrumen keterampilan sosial yaitu empati, berkomunikasi, bekerjasama, pengendalian diri, dan penyelesaian konflik. Dimensi dan indicator social skill dapat dilihat pada Tabel 6 . 
Tabel 6. Deskripsi dan Rentang Jawaban Indikator Keterampilan Sosial

\begin{tabular}{|c|c|c|c|}
\hline No & Dimensi & Indikator & Rentang Jawaban \\
\hline 1 & Empati & $\begin{array}{l}\text { Apakah merasa empati kepada orang } \\
\text { lain saat menghadapi kesulitan }\end{array}$ & $\begin{array}{l}1=\text { tidak pernah } \\
2=\text { kadang-kadang } \\
3=\text { sering } \\
4=\text { sangat sering }\end{array}$ \\
\hline 2 & berkomunikasi & $\begin{array}{l}\text { Seberapa sering berkomunikasi dengan } \\
\text { teman dan guru dalam memecahkan } \\
\text { masalah }\end{array}$ & $\begin{array}{l}1=\text { tidak pernah } \\
2=\text { kadang-kadang } \\
3=\text { sering } \\
4=\text { sangat sering }\end{array}$ \\
\hline 3 & Bekerjasama & $\begin{array}{l}\text { Apakah sering bekerjasama untuk } \\
\text { mengatasi pemasalahan }\end{array}$ & $\begin{array}{l}1=\text { tidak pernah } \\
2=\text { kadang-kadang } \\
3=\text { sering } \\
4=\text { sangat sering }\end{array}$ \\
\hline 4 & Pengendalian Diri & $\begin{array}{l}\text { Apakah mampu mengendalikan diri } \\
\text { dalam situasi yang tidak diharapkan }\end{array}$ & $\begin{array}{l}1=\text { tidak pernah } \\
2=\text { kadang-kadang } \\
3=\text { sering } \\
4=\text { sangat sering }\end{array}$ \\
\hline 5 & Penyelesaian Konflik & Apakah mampu menyelesaikan konflik & $\begin{array}{l}1=\text { tidak pernah } \\
2=\text { kadang-kadang } \\
3=\text { sering } \\
4=\text { sangat sering }\end{array}$ \\
\hline
\end{tabular}

Di dalam penerapan model pembelajaran Value Clarification Technique, terlihat bahwa peserta didik menampilkan sikap kerja sama yang baik dengan kelompoknya di dalam kelas. Aspek atau indicator kerjasama yang ditampakkan pada proses pembelajaran merupakan bagian dari keterampilan sosial yang dimiliki siswa. Penggunaan model Value Clarification Technique berguna dalam meningkatkan kerja sama pebelajar ketika proses pembelajaran melalui kegiatan berkelompok (Rachmadyanti \& Rochani, 2017). Lebih lanjut, pemakaian masalah dalam konteks kehidupan untuk di klarifikasi pada saat proses pembelajaran menggunakan model Value Clarification Technique menjadikan penyebab pebelajar aktif. Keterlibatan aktif pebelajar melalui masalah kontekstual yang ada dalam kehidupan mengakibatkan social skill peserta didik dapat berkembang baik. Sejalan dengan pendapat beberapa peneliti, penggunaan model Value Clarification Technique dengan memanfaatkan conten permasalahan yang kontekstual memberikan dampak positif terhadap social skill peserta didik (Nurasiah, 2019).
Pembelajaran dengan Value Clarification Technique (VCT) menitik beratkan interaksi sosial antar pebelajar, sehingga terbentuknya kerjasama untuk menyelesaikan permasalahan yang ada. Penelitian ini sejalan dengan penelitian yang dilakukan oleh Sulfemi \& Mayasari (2019) yang memaparkan bahwa ditemukan perbedaan yang signifikan social skill dan prestasi belajar antara pebelajar yang mengikuti pembelajaran dengan model VCT bermain peran dengan pebelajar yang menggunakan pembelajaran konvensional. Lebih lanjut menerangkan bahwa pebelajar dibina secara emosional dengan penglarifikasian, cara kritis, kebenaran, kelayakan serta ketepatanya dalam berfikir ketika menerapkan model VCT. Pada kegiatan proses belajar social skill peserta didik dapat meningkat dikarenakan adanya pemaparan materi yang diterangkan dengan cara bercerita mengenai dilemma atau permasalahan kehidupan. Selajutnya menjelaskan peserta didik menentukan pilihannya dengan melihat konsekuensi yang ditimbulkan dari pilihan tersebut. Sehingga hipotesis penelitian pada 
penelitian ini dapat diterima, artinya bahwa penggunaan model pembelajaran VCT dapat meningkatkan social skill mahasiswa program studi Pendidikan agama islam IIM Surakarta.

\section{SIMPULAN}

Berdasarkan penelitian yang telah dilakukan, diperoleh bahwa terdapat perbedaan yang signifikan social skill mahasiswa antara kelas eksperimen (kelas yang diperlakukan dengan menggunakan model VCT) dengan kelas control (kelas yang diberkalukan dengan model ekspositori). Hal ini dapat diartikan juga social skill mahasiswa prodi Pendidikan Agama Islam Institut Islam Mambaul Ulum

\section{DAFTAR RUJUKAN}

Adisusilo, S. (2012). Pembelajaran Karakter: Konstruktivisme dan VCT sebagai Inovasi Pendekatan Pembelajaran Afekif. Raja Grafindo Persada.

Agustin, N., \& Hamid, S. I. (2017). Pengaruh Model Pembelajaran Vct Terhadap Penalaran Moral Siswa Dalam Pembelajaran Pkn Sd. Jurnal Moral Kemasyarakatan, 2(1), 5974.

Anderson. (1956). Measurement and Evaluation in Psychology and Education. In Journal of the American Statistical Association (Vol. 51, Issue 275). https://doi.org/10.2307/2281462

Awiria, A., Nadiroh, N., \& Akbar, M. (2019). The Diversity of the National Culture of Elementary School Students Using the Value Clarification Technique Learning Model. International Journal of Multicultural and Multireligious Understanding, 6(3), 915. https://doi.org/10.18415/ijmmu.v6i 3.863
(IIM) Surakarta dengan menggunakan model VCT lebih tinggi dibandingkan mahasiswa yang menerapkan model ekspositori atau pembelajaran langsung. Berdasarkan hasil penelitian, diharapkan mahasiswa mampu meningkatkan social skill nya dengan baik agar dapat menjadi mahasiswa yang berkarakter, bermutu, dan berdaya saing tinggi. Penelitian ini masih sebatas pada lingkup program studi pendidikan agama islam di perguruan tinggi, diharapkan kedepanya diterapkan di program studi lain bahkan di terapkan di tingkat sekolah dasar sampai sekolah menengah atas.

Bremer, C. and S. J. (2004). Teaching Social Skills. National Center on Secondary Education and Transition, 3(5), 1-5. https://doi.org/10.1002/bin.163

Dewantara, J. A., Efriani, Sulistyarini, \& Prasetiyo, W. H. (2020). Optimization of Character Education Through Community Participation Around The School Environment (Case Study in Lab School Junior High School Bandung). Jurnal Etika Demokrasi, 5(1), 53-66.

Dong Hwa, C., \& Juhu, K. (2003). Practicing Social Skills Training for Young Children with Low Peer Acceptance: A Cognitive-Social Learning Model. Early Childhood Education Journal, 31(1), 41.

Hyder, I., \& Bhamani, S. (2016). Bloom's Taxonomy (Cognitive Domain) in Higher Education Settings: Reflection Brief. Journal of Education and Educational Development, 3(2), 288. https://doi.org/10.22555/joeed.v3i2. 1039 
Lawhon, T., \& Lawhon, D. C. (2000). Promoting social skills in young children. Early Childhood Education Journal, 28(2), 105-110. https://doi.org/10.1023/A:1009551 404906

Nurasiah, S. (2019). Meningkatkan Sikap Sosial Melalui Penerapan Model Pembelajaran Value Clarification Technique. Al-Aulad: Journal of Islamic Primary Education, 2(1), 84-92. https://doi.org/10.15575/alaulad.v2i1.4435

Rachmadyanti, P., \& Rochani, R. (2017). Pengembangan Social Skill Siswa Sekolah Dasar Melalui Teknik Pembelajaran Vct (Value Clarification Technique). DWIJA CENDEKIA: Jurnal Riset Pedagogik, 1(2), 70-78. https://doi.org/10.20961/jdc.v1i2.1 5290

Sariani, N. K. D., Dantes, N., \& Parmiti, De. P. (2016). Pengaruh Model Pembelajaran Value Clarification Technique ( Vct ) Terhadap Sikap Sosial Dan Hasil Belajar. E-Jurnal PGSD Universitas Pendidikan Ganesha, 4(1), 1-10.

Schwartz, M. J. (2005). The Modelling of moral Character by high school teachers through transformational leadership and emotional competence. Washington, D. C.: Pro Quest Information and Learning Company.

Sharma, R., Goswami, V., \& Punima, G. (2016). SOCIAL SKILLS : THEIR IMPACT ON ACADEMIC ACHIEVEMENT AND
Introduction: What are Social Skills? International Journal For Innovative Reserch In Multidisplinary Field, 2(7), 219224.

Sulfemi, W. B., \& Mayasari, N. (2019). The Use of Audio Visual Media in Value Clarification Technique to Improve Student Learning Outcomes in Social Studies. Jurnal Pendidikan, 20(1), 53-68. https://jurnal.ut.ac.id/index.php/jp/a rticle/view/235

Sutaryanto. (2015). Penerapan Model Value Clarification Technique (VCT) Berbantuan Film Dokumenter dalam Menanamkan Nilai Nasionalisme dan Meningkatkan Hasil Belajar Pada Siswa Sekolah Dasar. Premiere Educandum, 5, 237-252.

Taniredja, T., Faridli, E. M., \& Harimanto, S. (2015). Model Model Pembelajaran Inovatif dan Efektif. Alfabeta.

Tapia-Gutierrez, C. P., \& Delgado, S. C.-. (2015). Design of an Instrument to Assess Social Skills in Teacher Training Programs. Procedia Social and Behavioral Sciences, 197(February), 1074-1078. https://doi.org/10.1016/j.sbspro.201 5.07.342

Yudhistira, D., Djaenudin, R., \& Fitriyanti. (2015). Pengaruh Model Pembelajaran Klarifikasi Nilai Terhadap Sikap Kepedulian Sosial Peserta Didik Dalam Mata Pelajaran IPS di SMP Negeri 45 Palembang. Profit, 2(1), 28-33. 